\title{
SOEP
}

SOEPpapers

SOEPpapers
on Multidisciplinary Panel Data Research

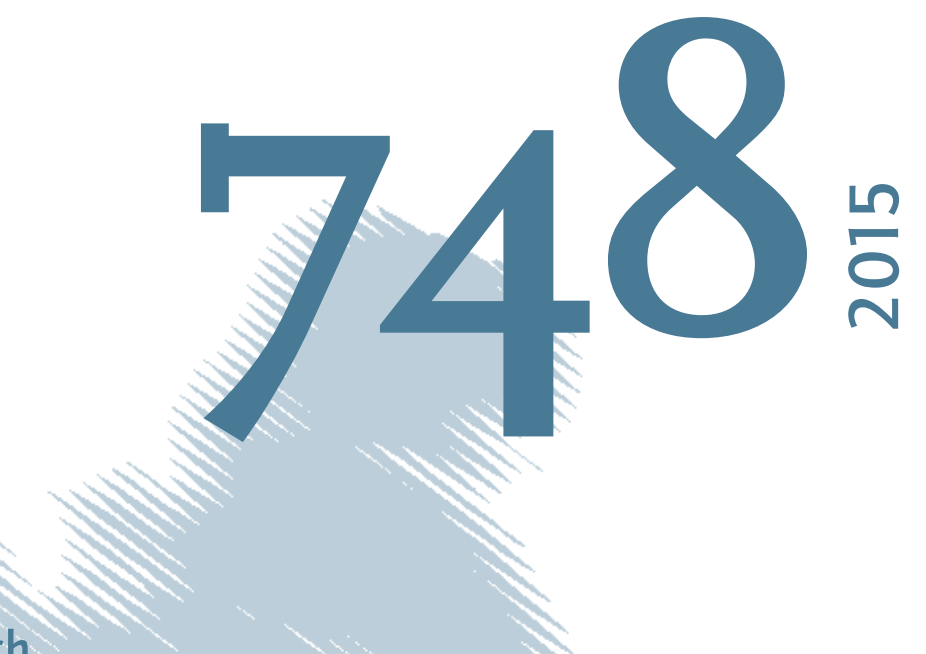

\section{Estimating Benefits from Regional Amenities: Internal Migration and Life Satisfaction}


This series presents research findings based either directly on data from the German SocioEconomic Panel study (SOEP) or using SOEP data as part of an internationally comparable data set (e.g. CNEF, ECHP, LIS, LWS, CHER/PACO). SOEP is a truly multidisciplinary household panel study covering a wide range of social and behavioral sciences: economics, sociology, psychology, survey methodology, econometrics and applied statistics, educational science, political science, public health, behavioral genetics, demography, geography, and sport science.

The decision to publish a submission in SOEPpapers is made by a board of editors chosen by the DIW Berlin to represent the wide range of disciplines covered by SOEP. There is no external referee process and papers are either accepted or rejected without revision. Papers appear in this series as works in progress and may also appear elsewhere. They often represent preliminary studies and are circulated to encourage discussion. Citation of such a paper should account for its provisional character. A revised version may be requested from the author directly.

Any opinions expressed in this series are those of the author(s) and not those of DIW Berlin. Research disseminated by DIW Berlin may include views on public policy issues, but the institute itself takes no institutional policy positions.

The SOEPpapers are available at http://www.diw.de/soeppapers

\section{Editors:}

Jan Goebel (Spatial Economics)

Martin Kroh (Political Science, Survey Methodology)

Carsten Schröder (Public Economics)

Jürgen Schupp (Sociology)

Conchita D'Ambrosio (Public Economics)

Denis Gerstorf (Psychology, DIW Research Director)

Elke Holst (Gender Studies, DIW Research Director)

Frauke Kreuter (Survey Methodology, DIW Research Fellow)

Frieder R. Lang (Psychology, DIW Research Fellow)

Jörg-Peter Schräpler (Survey Methodology, DIW Research Fellow)

Thomas Siedler (Empirical Economics)

C. Katharina Spieß (Education and Family Economics)

Gert G. Wagner (Social Sciences)

ISSN: 1864-6689 (online)

German Socio-Economic Panel Study (SOEP)

DIW Berlin

Mohrenstrasse 58

10117 Berlin, Germany

Contact: Uta Rahmann | soeppapers@diw.de 
Estimating Benefits from Regional Amenities: Internal Migration and Life Satisfaction

Angela Faßhauer ${ }^{\mathrm{a},{ }^{*}}$ and Katrin Rehdanz ${ }^{\mathrm{a}, \mathrm{b}}$

${ }^{a}$ Kiel Institute for the World Economy, Kiellinie 66, 24105 Kiel, Germany.

${ }^{\mathrm{b}}$ Department of Economics, University of Kiel, Olshausenstrasse 40, 24118 Germany.

*Corresponding author: formerly Kopmann. E-Mail: angela.fasshauer@ifw-kiel.de, Tel. +49-431-8814329.

\begin{abstract}
This paper is the first to link economic theory with empirical life-satisfaction analyses referring to internal migration. We derive an extension of the Roback (1982) model to account for benefits from regional amenities in the utility function, while controlling for income, housing costs, and migration costs. Using highly disaggregated spatial panel information on people's migration decisions and their life satisfaction for Germany, we provide an empirical investigation of the theoretical model by applying an individual fixed-effects model to rule out selection bias, while accounting for endogeneity of income. We find that short-term benefits from regional amenities represent about 21 percent of household income. These findings are robust to a number of alternative specifications.
\end{abstract}

Keywords: internal migration, regional amenities, life satisfaction, Germany.

JEL codes: A12, D6, I31, R23 


\section{Introduction}

Economic theory suggests that individuals will migrate if the benefits from migration are high enough to cover the associated costs. In a seminal paper, Roback (1982) shows that migration is determined by an equilibrium state of market rents and wages. Higher levels of regional amenities, such as climate or proximity to the coast, are offset by lower levels of wages or higher levels of rents, and utility is equalized over space. Bayer et al. (2009) have proposed the residential sorting model as an extension of the Roback model. It additionally accounts for migration costs in the utility function, modeling location choices to reveal benefits from regional amenities.

An alternative approach to measuring the benefits accruing from regional amenities is the life-satisfaction approach. Here, initial advances have recently been made in placing the approach on economic foundations (see Welsch and Ferreira, 2014). However, these advances are as yet limited when it comes to internal, i.e. within-country, migration. Due to data restrictions, previous empirical life-satisfaction studies on internal migration have proved unable to separate the migration effect into benefits from regional amenities and other factors, as economic theory would suggest (see e.g. Nowok et al., 2013 or Switek et al., 2012). However, in quality-of-life studies, regional amenities have been found to be important determinants of migration (alongside economic features) (see Rappaport, 2007 or Porell, 1982). The omission of such factors from empirical models has been recognized as a major limitation in early migration studies (see Graves 1979, 1980 and 1983).

The aim of this paper is to link empirical investigations of the effects of internal migration on life satisfaction with economic theory. More specifically, we extend the previous literature in two ways. First, in a theoretical section, we extend the Roback (1982) model to derive an indirect utility function that accounts for benefits from regional amenities alongside income, housing costs, and migration costs. Second, in our empirical section we directly estimate this indirect utility function, using life satisfaction as a proxy for experienced utility with the ultimate goal of providing a monetary measure for benefits deriving from changes in regional amenities. Unlike earlier empirical studies on internal migration, we are able to (1) separate effects from changes in housing costs, effects from migration costs, and a remaining migration effect representing benefits from regional amenities, while (2) employing data that are much more spatially disaggregated.

In this article, we take advantage of one of the assets of the German Socio-Economic Panel (SOEP), i.e. that of providing regional information on the residences of households at 
the municipality level, which is the lowest level of official territorial division in Germany. ${ }^{1}$ By presenting evidence from a large representative panel dataset, we address several concerns that are common in connection with cross-sectional data. When focusing on regional amenities, selection bias arises if individuals with specific characteristics are selected into regions with higher (lower) levels of regional amenities. Assume, for example, that extrovert people are more satisfied and tend to be more prone to migration, improving their situation by migrating to regions with higher levels of regional amenities. This causes an overestimation of benefits from regional amenities in regions with higher amenity levels (and, similarly, an underestimation in regions with lower amenity levels). The use of panel data providing repeated observations of individuals over time enables us to overcome potential selection bias by controlling for time-invariant individual fixed effects in the empirical analysis.

We begin the analysis by asking to what extent benefits from changes in regional amenities beyond income, housing costs, and migration cost differentials exist in general for the working age population. At the same time, we control for other socio-economic characteristics. In the next stage, we test whether our findings are robust to various sources of bias from omitted variables, such as housing characteristics, social ties, and regional economic characteristics. The final step is then to derive from the empirical model a conservative monetary measure for the trade-off between income and benefits from changes in regional amenities. Here we instrument income with predicted labor earnings in the wake of Luechinger (2009) and Vendrik (2013).

Our main findings indicate that short-term net benefits from changes in regional amenities due to migration are equivalent to 21 percent of household income. These benefits from regional amenities are much larger than migration-related income gains, which represent only 3 percent of household income. However, these benefits also involve costs that partly mitigate their effect. Housing costs measure 3 percent of household income. Migration costs represent 1.5 percent of household income, but in statistical terms, they do not differ significantly from zero.

The paper is structured as follows: In Section 2 we present an overview of previous research. In Section 3 we provide information on the theoretical background and the empirical specification. The data set is described in Section 4. In Section 5 we present our empirical findings. Robustness results are discussed in Section 6. In Section 7 we monetize benefits from regional amenities. Our conclusions are presented in Section 8.

\footnotetext{
${ }^{1}$ The average size of municipalities in our sample is $63 \mathrm{~km}^{2}$.
} 


\section{Previous Research}

\subsection{Studies based on the hedonic model and the residential sorting model}

Previous empirical studies aiming to determine benefits from regional amenities are either based on Roback's (1982) hedonic model or, more recently, on residential sorting models (see Bayer et al. 2009). In hedonic studies, the coefficient obtained by regressing wages or house prices on regional amenities can be used to calculate the marginal willingness-to-pay (MWTP) for changes in regional amenities. Regional amenities that have been valued in the literature in this way include air quality and open space. Applying house price regressions for large U.S. cities, Zabel and Kiel (2000) find a negative MWTP for a one-unit increase in the concentration of particulate matter, indicating air pollution as being a disamenity. Using house price regressions for central Maryland, Irwin (2002) finds a positive MWTP for permanently preserved open space relative to developable agricultural land and forests. For a summary, see Waltert and Schläpfer (2010). However, the Roback model rests upon assumptions that do not necessarily hold, thus causing potential bias in the estimates. The first of these is that migration equalizes utility (market equilibrium), the second that migration is costless (see Mäler, 1977).

To offset the latter limitation, Bayer et al. (2009) propose the use of a residential sorting model. This extends the Roback model by explicitly accounting for migration costs in the utility function. The residential sorting model provides MWTP estimates for changes in regional amenities by estimating a discrete choice model for the probability that individuals will locate in a specific region. Similarly to Zabel and Kiel (2000), Bayer et al. (2009) find negative MWTP estimates for ambient concentrations of particulate matter when applying the residential sorting model. They also find that estimates are 3.5 times larger from the residential sorting model with migration costs than from hedonic regression without migration costs. Application of the residential sorting model is however limited. Klaiber and Phaneuf (2010) find that the MWTP for an increase of non-park open space is higher (lower) for households with higher (lower) income. Sinha and Cropper (2013) find a positive MWTP for higher winter temperatures and a negative MWTP for higher summer temperatures.

\subsection{Life satisfaction analyses and internal migration}

The hedonic model and the residential sorting model make no use of the indirect utility function as such. The approach we present estimates the indirect utility function by using life 
satisfaction as a proxy for experienced utility. Several earlier studies have focused on validation tests for life satisfaction as a proxy for experienced utility. It transpires that lifesatisfaction scores are correlated with other variables associated with true individual wellbeing (see Frey and Stutzer, 2002), which supports the validity of life satisfaction as a proxy for experienced utility. To overcome possible limitations related to interpersonal comparison, an increasing number of studies analyze intrapersonal changes in life satisfaction by using individual panel information.

Life-satisfaction studies have focused on individual benefits of household income, leisure activities, individual costs of commuting, physical and mental health, and environmental amenities and disamenities (see Welsch and Ferreira (2014) for a recent review of the literature). Only very few of them explicitly link life satisfaction with internal migration. Switek (2012) finds positive short-term effects on life satisfaction from internal migration within Sweden. These effects are driven by housing satisfaction for non-work-migrants and improvements in occupational position for work-migrants. Empirical findings by Nowok et al. (2013) do not suggest any long-term effects from internal migration for the UK. Instead, significant declines in life satisfaction in the four years before migration are offset by increases in life satisfaction from migration, with people re-attaining their initial levels throughout the five years following migration. Findings by Nowok et al. (2013) also suggest that despite the higher social and psychological costs involved, the level of life satisfaction for long-distance migrants ( $\geq 25 \mathrm{~km}$ ) is at least as high as the level of life satisfaction for shortdistance migrants $(<25 \mathrm{~km})$. Studies analyzing internal migration decisions for Germany are based on information concerning East-West migration subsequent to German reunification in 1990. These studies suggest that significant increases in life satisfaction in the years after migration apply to permanent East-West migrants only (see Fuchs-Schündeln and Schündeln, 2009).

Existing life-satisfaction studies on internal migration are limited in two ways. First, they are unable to control for important factors such as housing costs or migration costs, providing instead aggregate effects of internal migration. Second, they focus on migration between aggregated regions. In the case of Germany, for example, they only differentiate between East and West when focusing on migration decisions linked to German reunification (FuchsSchündeln and Schündeln, 2009). 


\section{Theory and Empirical Specification}

\subsection{Utility maximization and regional amenities}

Following Roback (1982), we assume that each individual $i$ in region $j$ maximizes utility subject to a budget constraint by choosing the quantity of consumption of a numeraire good $C$ and units of housing $H$. The level of region-specific regional amenities is given by $A$. Following Bayer et al. (2009), we extend the Roback model by considering migration costs $M C$. These are independent of location, i.e. they capture social and psychological costs and do not appear in the budget constraint. Finally, individuals have identical preferences.

The utility function is given as follows:

$$
U=f(C, H, A, M C),
$$

where $U$ reflects the level of utility.

An individual maximizes utility given the following budget constraint:

$$
Y-C-R H=0,
$$

where $R$ represents housing costs per unit of housing. Substituting optimal values of consumption and housing, we obtain the following indirect utility function: ${ }^{2}$

$$
V(Y-R, A, M C)=k \text {, }
$$

where $k$ is the common level of utility. The level of amenities in a region shifts the indirect utility function $V$ upwards or downwards, depending on whether it is an amenity (benefits) or disamenity (costs). Migration costs shift the indirect utility function downwards.

According to this view, migration takes place as a result of equating the benefits and costs of migration. Any region with a higher level of regional amenities will experience inmigration until, in some combination, income $Y$ falls or housing costs per unit of housing $R$ rise sufficiently to eliminate the utility differential (see Greenwood, 1997). The net impact of changes in the level of amenities is then zero:

$$
\frac{\mathrm{d} V}{\mathrm{~d} A}=\frac{\delta V}{\delta A}+\frac{\delta V}{\delta Y} \frac{\mathrm{d} Y}{\mathrm{~d} A}+\frac{\delta V}{\delta R} \frac{\mathrm{d} R}{\mathrm{~d} A}+\frac{\delta V}{\delta M C} \frac{\mathrm{d} M C}{\mathrm{~d} A}=0 .
$$

As shown in equation (4), the marginal utility from regional amenities $\delta V / \delta A$ is offset by marginal net disutility from changes in income $\delta V / \delta Y \mathrm{~d} Y / \mathrm{d} A$, housing costs $\delta V / \delta R \mathrm{~d} R / \mathrm{d} A$, and migration costs $\delta V / \delta M C \mathrm{~d} M C / \mathrm{d} A$ in equilibrium.

\footnotetext{
${ }^{2}$ See Appendix A.1 for the derivation.
} 


\subsection{Empirical specification}

Taking advantage of the panel structure of our dataset, we control for various sources of omitted variable bias using individual fixed effects. In analyzing benefits from regional amenities, one major concern is selection bias. This occurs because people select themselves into regions with higher (lower) levels of regional amenities depending on their individual characteristics. For example, extrovert people tend to be more satisfied with their lives, while at the same time tending to be more prone to migration, feeling that they can improve their situation by migrating to regions with higher levels of regional amenities. In cross-section analyses, the benefits from changes in regional amenities are then overestimated in regions with higher levels of regional amenities (and underestimated in regions with lower levels of amenities). If panel information is available, the individual fixed-effects approach can partly overcome this limitation. In addition to observable time-varying characteristics explicitly considered in the analysis, such as age or health, the approach enables researchers to control for time-invariant individual characteristics such as personality traits. Along with individual fixed effects, regional fixed effects are also controlled for. To control for policy shocks that affect all individuals similarly and may also affect an individual's decision to migrate (such as the financial crisis, which increases the probability of job-related migration decisions), we include year-fixed effects.

In an individual fixed-effects model, coefficients are estimated on the basis of information about changes in variables over time, which is why, in our analysis, we identify benefits from regional amenities through changes in the level of regional amenities caused by migration. In the literature, one standard approach is to separate region-specific effects for obtaining benefits from regional amenities by including regional dummies (see e.g. Moro et al. 2008). However, given that the number of internal migrants is limited in general surveys (including ours), we prefer to estimate an average effect from regional amenities rather than separating out region-specific effects. We do this by setting $A$ (the regional amenity) equal to $M_{i, t}$, where $M_{i, t}$ is a migration dummy taking the value of one if an individual $i$ migrates at time $t$, and zero otherwise. Given that other important factors (income, housing costs, migration costs, individual characteristics, regional fixed effects) are controlled for, the coefficient of the migration dummy $\beta_{a}$ reflects an average immediate migration effect that provides a proxy for average benefits from changes in regional amenities due to migration. 
Taking these controls into account and assuming a Cobb-Douglas utility function (see Appendix A.1 for a derivation) for measuring indirect utility $V$, we estimate our baseline model by rewriting equation (3) as follows:

$$
L S_{i, j, t}=\beta_{y} \ln Y_{i, t}+\beta_{x} X_{i, t}-\beta_{h} \ln R_{i, j, t}+\beta_{a} M_{i, t}+\beta_{d} D_{i, t}+\mu_{t}+v_{i}+\varepsilon_{i, j, t},
$$

where $L S_{i, j, t}=\ln \left(\exp \left(L S_{i, j, t}\right)\right)=\ln V$, which represents reported life satisfaction of individual $i$ in region $j .{ }^{3} X_{i, t}$ are socio-economic characteristics detailed below. Migration costs $M C$ are given by $\beta_{d} \mathrm{D}_{i, t}$, where the coefficient $\beta_{d}$ reflects the unit costs of migration $\left(\mathrm{MC}_{i} / \mathrm{D}_{i, t}\right)$ and $\mathrm{D}_{i, t}$ is the migration distance for individual $i$ at time $t$. We assume that migration costs $M C$ are only greater than zero for migrants in the period of migration; otherwise they are zero. Finally, $\mu_{t}$ are year-fixed effects, $v_{i}$ are individual fixed effects, $\varepsilon_{i, j, t}$ is the error term, and $\beta_{y}$, $\beta_{x}, \beta_{h}$ are further coefficients to be estimated.

In a second step, we extend the baseline model controlling for other individual and regional characteristics that are not standard in life-satisfaction analyses, but which might simultaneously influence the dependent variable (life satisfaction) and the decision to migrate, thus causing potential bias in the effect of migration on life satisfaction. More specifically, we consider housing and neighborhood characteristics (first extension), social ties (second extension), and regional economic characteristics (third extension).

So far, the thing that all model specifications have in common is that endogeneity of income may bias the income coefficient downwards. A downward bias in the income coefficient is of major concern in our analysis as it causes an upward bias in the trade-off between income and the migration effect, which provides a monetary estimate for benefits from regional amenities (see Section 7). Potential sources of downward bias in the income coefficient are individual efforts leading to higher earnings and positively affecting life satisfaction (see Luechinger, 2009) or measurement errors in income (see Vendrik, 2013). To correct for downward bias in the income coefficient, we follow Luttmer (2005), Luechinger (2009), and Vendrik (2013) and use predicted labor earnings as an instrument in the fourth and final extension of the baseline model.

\footnotetext{
${ }^{3}$ Life satisfaction is left skewed. As is standard in the literature, we assume an exponential transformation of this variable to obtain a normal distribution.
} 


\subsection{Estimation method}

Two methods can be applied to estimate the above models. First, ordered logit can be used to account for a non-linear relationship or ordinality in the dependent variable. However, this requires averaging the marginal effects to calculate the effects on life satisfaction, which is open to criticism. Second, Ordinary Least Squares (OLS) can be applied when error terms are adjusted for heteroscedasticity, which may be less accurate due to the cardinality assumption. Ferrer-i-Carbonell and Frijters (2004) have shown that controlling for individual fixed effects is much more important than assuming ordinality or cardinality of the dependent variable in life-satisfaction analyses. In our analysis, we use OLS to estimate the model for greater ease of interpretation and apply (ordered) logit for a robustness check. As expected, the results are not affected.

Estimating an empirical life-satisfaction model with individual panel information at a regional level raises two issues. First, observations may be correlated across individuals over time, and/or second, observations may be correlated within regions as people living in the same region tend to be more similar than they would be otherwise. It is important to cluster standard errors at the appropriate level, as this relaxes the assumption that observations are independent and adjusts standard errors for intra-personal and/or intra-regional correlation accordingly (see Moulton, 1990). Estimating the model without clustering at the appropriate level yields standard errors that are too small, thus too often suggesting a rejection of the null. To overcome this issue, we tested for clustering of errors at the individual level $i$ and at the regional level $j$. Results show that clustering at the individual level yields more conservative inferences of migration effects than clustering at the regional level or two-way clustering at both the individual and the regional level. This is why we cluster at the individual level throughout the paper. Finally, we weight regressions with panel sampling weights provided by the SOEP to adjust for differences in the sampling design over and against the true population.

\section{Data}

Our analysis is based on data taken from the German Socio-Economic Panel (SOEP) for five consecutive years (2006 to 2010). The Panel is a representative longitudinal study providing socio-economic information on approximately 20,000 individuals and 10,000 households in Germany (see Wagner et al., 2007). We restrict our sample to those aged between 18 and 63, the latter representing the average retirement age in Germany in 2006 
(DRV, 2012). ${ }^{4}$ In the SOEP, information on life satisfaction (our dependent variable) is obtained by asking individuals the following question: "All things considered, how satisfied would you say you are with your life these days?” Respondents can choose from an ordinal scale of 0 to 10 , where 0 stands for very dissatisfied and 10 for very satisfied.

We investigate migration at the lowest level of official territorial division in Germany, the municipality level. ${ }^{5}$ We classify those individuals that move across administrative borders of municipalities as migrants. Since on average the area of a municipality is small, we assume that (for 'within' municipality movers) regional amenities, the social, and the working environment do not change. However, we add a dummy variable for moving 'within' municipalities to control for any such effects. In the SOEP, the share of migrants is $5.8 \%$ per year on average (which equals 555 migrants). This is very close to figures from the Federal Statistical Office of Germany (Statistisches Bundesamt) according to which $5.4 \%$ of Germans moved across the administrative borders of municipalities in $2006 .{ }^{6}$ Our final sample consists of 43,941 observations (or 9,562 persons) and 8,745 municipality-year combinations (or 1,746 municipalities).

In addition, we consider a large number of socio-economic characteristics provided by the SOEP that in previous studies have been found to have an impact on life satisfaction. These include net household income (after tax), citizenship, age, number of persons in household, gender, marital status ${ }^{7}$, employment status, years spent in education, and health status (see e.g. Dolan et al., 2008). We further control for housing costs per $\mathrm{m}^{2}$ (square meter). ${ }^{8}$ Both net household income and housing costs per $\mathrm{m}^{2}$ are adjusted in two ways. First, we deflate both variables via a consumer price index to account for the fact that nominal increases in these variables do not affect people's life satisfaction, whereas real increases do. Second, we apply equivalence scales to account for the fact that the needs of a household grow with the number

\footnotetext{
${ }^{4}$ In our analysis below, early retirees are classified as 'non-working'.

${ }^{5}$ There were more than 12,000 municipalities in Germany with an average size of $29 \mathrm{~km}^{2}$ in 2006 (Statistisches Bundesamt). Since their number changes over the sample period, we distinguish 11,449 regions. Data can be accessed at: www.destatis.de.

${ }^{6}$ Own calculations based on information from the Federal Statistical Office (Statistisches Bundesamt) for 2006; share of 'within' migrants (excluding immigrants from other countries) compared to total population as at 31.12.2006. Data can be accessed at: www.destatis.de.

${ }^{7}$ To control for any effects from moving in with a partner, we combine this with information on marital status ("being married”, etc.) (see Luechinger, 2009).

${ }^{8}$ The SOEP provides information on rents for tenants and imputed rents, which are estimated rents for house owners and tenants with reduced rents (see Krause (1996) for more information). Rents are the monthly rent charged, including utilities but excluding heating costs. Rents are divided by the size of the flat/house to obtain a measure for rents per unit of housing.
} 
of members in it, albeit not proportionally (due to economies of scale in consumption). ${ }^{9}$ To capture the unit costs of migration, we use Euclidean distance as a measure for migration distance calculated from the coordinates of the centroids of the municipalities. Summary statistics for variables in our baseline model are provided in Appendix A.2.

To control for bias from other sources that are not standard controls in life satisfaction analyses, we consider additional characteristics in expansions of the baseline model. First, we control for housing (size, construction year, ownership, equipment, condition of the flat/house) and neighborhood characteristics. ${ }^{10}$ Second, we consider the extent of social participation by calculating an equally weighted mean of the frequency of responses to 'helping out friends, relatives or neighbors' and 'meeting friends, relatives or neighbors,' as suggested by Headey et al. (2013). Third, we control for economic characteristics of regions. We use Euclidean distance from each municipality to the nearest large city to control for accessibility of services provided in large cities. ${ }^{11}$ To control for the prosperity of a region, we also use information on regional purchasing power and regional unemployment obtained from the BBSR. Finally, for the instrumentation of income we use predicted labor earnings. These are obtained by regressing the natural logarithm of labor earnings provided by SOEP for each individual on industry and occupation dummies for each year, separately for West and East Germany. The exponential of the predicted value is summed up over household members, which yields a final measure on predicted labor earnings (see Vendrik, 2013). ${ }^{12}$ In instrumenting income with predicted labor earnings, we extend the empirical model with additional controls for labor characteristics (contract length, job tenure, actual working hours and its squared term). Summary statistics for variables used in extensions of the baseline model are presented in Table A.4 in the Appendix.

\footnotetext{
${ }^{9}$ In line with the modified OECD scale, we assign a value of 1 to the first person in the household, 0.5 to every other person aged 14 and older, and 0.3 to all children below the age of 14 . Housing costs and net household income are both divided by the sum of these values, resulting in needs-adjusted values (see Atkinson and Bourguignon, 2000). The advantage of using equivalence scales is that the effects of marginal changes in these variables can be interpreted on a hypothetical per-person basis.

${ }^{10}$ Zumbro (2014) controls for housing characteristics using SOEP to analyze the relationship between life satisfaction and home ownership.

${ }^{11}$ We define large cities on the basis of BBSR structural municipality types: (1) major large cities, (2) large cities in agglomeration counties, and (3) large cities in urban counties; see Table A.3 in the Appendix.

${ }^{12}$ Following Luechinger (2009), we exclude self-employed people from the sample before estimating labor earnings, as they tend to be more reluctant to state their income.
} 
(1)

\begin{tabular}{|c|c|c|c|c|c|}
\hline \multirow[b]{2}{*}{ Life satisfaction } & \multicolumn{5}{|c|}{ Baseline Model } \\
\hline & Coef. & t-stat & & Coef. & t-stat \\
\hline \multicolumn{6}{|l|}{ Socio-economic characteristics } \\
\hline Log real equivalent net household income & $0.1279 *$ & 1.91 & Not working & \multicolumn{2}{|c|}{ Reference group } \\
\hline Log real equivalent household rents $/ \mathrm{m}^{2}$ & -0.0079 & -0.42 & Unemployed & $-0.5048 * * *$ & -5.38 \\
\hline Age squared & $0.0008 *$ & 1.87 & Student & 0.0914 & 0.67 \\
\hline Number of people living in hh & $0.1154 * *$ & 2.17 & Military, civilian services & -0.0714 & -0.44 \\
\hline Number of children & 0.0919 & 1.45 & Working & 0.0453 & 0.58 \\
\hline Not hospitalized last year & \multicolumn{2}{|c|}{ Reference group } & German Citizen & \multicolumn{2}{|c|}{ Reference group } \\
\hline Hospitalized last year & $-0.1107 * *$ & -2.33 & Non-German citizen & $0.4445 *$ & 1.85 \\
\hline Single, not living with partner & \multicolumn{2}{|c|}{ Reference group } & First interview & $0.2518 * *$ & 2.42 \\
\hline Single, living with partner & 0.0382 & 0.29 & Second interview & 0.0914 & 1.03 \\
\hline Married, living with partner & 0.0467 & 0.24 & Third or subsequent interview & \multicolumn{2}{|c|}{ Reference group } \\
\hline Separated, not living with partner & -0.4508 & -1.59 & No moves 'within' municipalities & \multicolumn{2}{|c|}{ Reference group } \\
\hline Separated, living with partner & -0.0140 & -0.05 & Move 'within' municipalities & 0.0101 & 0.14 \\
\hline Divorced, not living with partner & -0.0634 & -0.20 & & & \\
\hline Divorced, living with partner & -0.4271 & -1.33 & Effects from migration & & \\
\hline Widowed, not living with partner & -0.4879 & -0.97 & Not migrating 'across' municipalities & \multicolumn{2}{|c|}{ Reference group } \\
\hline Widowed, living with partner & 0.3577 & 0.49 & Migrating 'across' municipalities & $0.3101 * *$ & 2.46 \\
\hline Years in education & 0.0073 & 0.25 & Migration distance & -0.0174 & -0.19 \\
\hline Individual fixed effects & Yes & & Average observation per person & 4.6 & \\
\hline Year effects & Yes & & Observations & 43,941 & \\
\hline Number of persons & 9,562 & & Adjusted R-squared within & 0.0181 & \\
\hline
\end{tabular}

Tab. 1: Migration effects and satisfaction with life across German municipalities

Source: Own calculations. Model estimated by OLS. Robust standard errors are clustered for person number, and t-statistics are reported. * indicates significant at the 10 percent level, ** at the 5 percent level, and *** at the 1 percent level. 


\section{Empirical Results}

\subsection{Baseline model}

The results of the baseline model are presented in Table 1. The effects of socio-economic characteristics on life satisfaction are similar to those typically found in the literature (see Dolan et al., 2008). Our findings indicate a positive diminishing effect of income on life satisfaction. The effect of housing costs per $\mathrm{m}^{2}$ on life satisfaction is negative but insignificant. We also find a positive effect of age squared, which is in line with a U-shaped relationship between age and life satisfaction established in earlier studies (see Ree and Alessie, 2011). ${ }^{13}$ Furthermore, the number of persons living in a household positively affects life satisfaction, while hospitalization in the previous year or redundancy have a negative effect. Being a non-German citizen or having the first interview relative to having the third or subsequent interview have a positive effect on life satisfaction. While effects from moving 'within' municipalities are close to zero and insignificant, we find a positive and significant effect on life satisfaction from migrating 'across' municipalities. Not only is the effect from migration statistically significant at the 5 percent level, it also exerts an effect equivalent to more than half the magnitude of the effect of negative events on life satisfaction, such as redundancy (0.3101 as compared to -0.5048 for redundancy). The effect of migration distance (our measure for the costs of migration) on life satisfaction is negative, as expected, but insignificant.

\subsection{Extensions of the baseline model}

To rule out omitted-variable bias, the model specifications presented in the following expand the baseline model by successively adding control variables that may simultaneously affect the dependent variable (life satisfaction) and the decision to migrate. This reduces our sample size. To account for this reduction, we compare the results of the extension to the previous model specification with adjusted sample size to assess the impact of further controls on migration effects. To ensure that the number of migrants is sufficiently large, we only retain those new control variables in subsequent model specifications if they have an impact on migration effects.

\footnotetext{
${ }^{13}$ In our model, the level effect of individual age is absorbed by individual fixed effects.
} 


\begin{tabular}{llrrrr}
\hline & \multicolumn{2}{c}{$(1)$} & \multicolumn{2}{c}{$(2)$} \\
Life satisfaction & \multicolumn{2}{c}{ Baseline Model } & \multicolumn{2}{c}{ Housing } \\
\hline Socio-economic characteristics & Coef. & t-stat & Coef. & t-stat \\
\hline Log real equivalent net household income & $0.1645 * *$ & 2.15 & $0.1707 * *$ & 2.29 \\
Log real equivalent household rents $/ \mathrm{m}^{2}$ & -0.0164 & -0.88 & $-0.0436 * *$ & -1.98
\end{tabular}

\section{Migration effects}

Not migrating 'across' municipalities

Migrating 'across' municipalities

\begin{tabular}{crrr}
\multicolumn{2}{c}{ Reference group } & \multicolumn{2}{c}{ Reference group } \\
$0.3007 * *$ & 2.49 & $0.2918 * *$ & 2.52 \\
-0.0652 & -0.51 & -0.0557 & -0.45
\end{tabular}

Migration distance

$-0.0652$

$-0.51$

$-0.45$

Housing and neighborhood characteristics

Logarithm of size of house/flat in $\mathrm{m}^{2}$

$\begin{array}{lr}-0.0980 & -1.13 \\ -0.0319 & -0.17 \\ 0.0202 & 0.11 \\ 0.0541 & 0.32 \\ -0.0818 & -0.49 \\ -0.5441 * * * & -2.84 \\ 0.0839 & 0.47\end{array}$

Construction year: $<1918$

Construction year: 1918 - 1948

Reference group

Reference group

Not owner of house/flat

Owner of house/flat

No central heating

$-0.3061 * * * \quad-2.82$

Reference group

With central heating

0.1953

1.50

No balcony/terrace

Reference group

With balcony/terrace

No basement

$-0.0621$

$-1.11$

Reference group

With basement

$-0.0605$

$-0.87$

No garden

With garden

No kitchen in house/flat

Reference group

$-0.0828$

$-1.10$

Kitchen in house/flat

With hot running water/boiler in house/flat

No hot running water/boiler in house/flat

No telephone in house/flat

With telephone in house/flat

House/flat in good shape

House/flat needs to be refurbished

Detached or semi-detached house

Farm building

Reference group

0.0380

0.14

Reference group

$-0.1913$

$-0.85$

Reference group

$0.3408 * * \quad 1.98$

Reference group

$-0.0938 * \quad-1.96$

Reference group

Terraced house

$-0.4176 \quad-1.28$

$0.1263 \quad 0.84$

Apartment or other building

$-0.1694 \quad-1.44$

High-rise building

$-0.7798 * * * \quad-2.70$

Private household

Reference group

Hall of residence/home

0.3062

0.93 


\begin{tabular}{|c|c|c|c|c|}
\hline \multirow[b]{2}{*}{ Life satisfaction } & \multicolumn{2}{|c|}{$\begin{array}{c}\text { (1) } \\
\text { Baseline Model }\end{array}$} & \multicolumn{2}{|c|}{$\begin{array}{c}\text { (2) } \\
\text { Housing }\end{array}$} \\
\hline & Coef. & t-stat & Coef. & t-stat \\
\hline Industrial area & & & \multicolumn{2}{|c|}{ Reference group } \\
\hline Residential area with old buildings & & & $0.4705 * *$ & 2.45 \\
\hline Residential area with new buildings & & & $0.5835 * * *$ & 2.91 \\
\hline Mixed or other area & & & $0.4446 * *$ & 2.40 \\
\hline Commercial center & & & 0.7178 & 1.13 \\
\hline Individual fixed effects & Yes & & Yes & \\
\hline Year effects & Yes & & Yes & \\
\hline Number of persons & 9,315 & & 9,315 & \\
\hline Average observation per person & 4.5 & & 4.5 & \\
\hline Observations & 41,764 & & 41,764 & \\
\hline Adjusted R-squared within & 0.0172 & & 0.0220 & \\
\hline
\end{tabular}

Tab. 2: Migration effects, housing and neighborhood characteristics

Source: Own calculations. All models estimated by OLS. Robust standard errors clustered for person number and t-statistics reported.* indicates significant at the 10 percent level, ** at the 5 percent level, and $* * *$ at the 1 percent level. Socio-economic controls as provided in Table 1 are included but not presented here.

In a first extension of the baseline model presented in Table 2, we control for housing and neighborhood characteristics. Changes in housing and neighborhood characteristics may simultaneously affect life satisfaction and the decision to migrate. They may also bias the migration effect upwards or downwards, depending on whether migration involves an improvement or a deterioration of housing and neighborhood characteristics. Including housing and neighborhood controls reduces the sample size from 43,941 to 41,764 and the number of 'across'-municipality migrants from 555 to 465. In column (2) of Table 2, we find that living in a house constructed between 1981 and 1990 negatively affects life satisfaction compared to living in a house constructed after the year 2000. Our findings also suggest that life satisfaction is negatively affected by living in a high-rise building as opposed to a detached or semi-detached house, owning the house/flat, or the need for refurbishment of living quarters. Having a telephone positively affects life satisfaction. Finally, living in a residential area with old or new buildings or living in a mixed or other area has a positive effect on life satisfaction compared to living in an industrial area. Of these effects, that of living in a residential area with new buildings is the most influential.

As we see in Table 2, controlling for housing and neighborhood characteristics (column 2) has a minor effect on the coefficients included in the baseline model (column 1); the estimated coefficient for migration is 3 percent lower. Similarly, the income coefficient decreases, while its level of significance increases to the 5 percent level. The coefficient of housing costs is now significant at the 5 percent level in both specifications presented in Table 2. The effect of migration distance remains negative and insignificant. 


\begin{tabular}{|c|c|c|c|c|}
\hline \multirow[b]{2}{*}{ Life satis faction } & \multicolumn{2}{|c|}{$\begin{array}{c}\text { (1) } \\
\text { Housing }\end{array}$} & \multicolumn{2}{|c|}{$\begin{array}{c}\text { (2) } \\
\text { Housing \& social ties }\end{array}$} \\
\hline & Coef. & t-stat & Coef. & t-stat \\
\hline \multicolumn{5}{|l|}{ Socio-economic characteristics } \\
\hline Log real equivalent net household income & $0.3015 * * *$ & 2.70 & $0.3043 * * *$ & 2.72 \\
\hline Log real equivalent household rents $/ \mathrm{m}^{2}$ & $-0.0920 * *$ & -2.36 & $-0.0958 * *$ & -2.45 \\
\hline \multicolumn{5}{|l|}{ Migration effects } \\
\hline Not migrating 'across' municipalities & \multicolumn{2}{|c|}{ Reference group } & \multicolumn{2}{|c|}{ Reference group } \\
\hline Migrating 'across' municipalities & $0.4330 * *$ & 2.35 & $0.4277 * *$ & 2.33 \\
\hline Migration distance & -0.1394 & -0.78 & -0.1302 & -0.75 \\
\hline \multicolumn{5}{|l|}{ Social ties } \\
\hline Social participation & & & $0.1257^{* * *}$ & 3.01 \\
\hline Individual fixed effects & Yes & & Yes & \\
\hline Year effects & Yes & & Yes & \\
\hline Number of persons & 9,120 & & 9,120 & \\
\hline Average observation per person & 2.7 & & 2.7 & \\
\hline Observations & 24,280 & & 24,280 & \\
\hline R-squared within & 0.0323 & & 0.0344 & \\
\hline
\end{tabular}

Tab. 3: Migration effects and social ties

Source: Own calculations. All models estimated by OLS. Robust standard errors clustered for person number and t-statistics reported. * indicates significant at the 10 percent level, ** at the 5 percent level, and *** at the 1 percent level. Socio-economic controls as provided in Table 1 are included but not presented here.

In a second extension of the baseline model presented in Table 3, we add information on social participation as a measure of social ties. Existing social ties with the destination region may (a) simultaneously and positively affect life satisfaction and the decision to migrate and (b) bias migration effects upwards. ${ }^{14}$ As information on social ties is only available for three years in our sample period, the inclusion of social ties reduces the sample size from 41,764 to 24,280 and the number of migrants from 465 to 280.

Our results presented in Table 3 suggest that social ties have a positive and highly significant effect on life satisfaction. Comparing columns (1) and (2), the effect on migration and on socio-economic characteristics is, however, largely negligible. The effect on migration is 1 percent smaller. The effect of migration distance remains negative and insignificant. There is no change regarding the effect of income, but the coefficient is now significant at the 1 percent level compared to the results presented in Tables 1 and 2 . The coefficient for housing costs per $\mathrm{m}^{2}$ is significant at the 5 percent level in both specifications presented in Table 3; the negative coefficient is 4 percent larger when controlling for social ties. Overall, controlling for social ties causes major observation losses and only has a negligibly minor

\footnotetext{
${ }^{14}$ Social ties in the region of origin might bias the migration effect as well, causing, however a downward bias. In general, we are more concerned with overestimating benefits from regional amenities. For this reason, we do not consider this further.
} 


\begin{tabular}{|c|c|c|c|c|}
\hline \multirow[b]{2}{*}{ Life satisfaction } & \multicolumn{2}{|c|}{$(1)$} & \multicolumn{2}{|c|}{ (2) } \\
\hline & Coef. & t-stat & Coef. & t-stat \\
\hline \multicolumn{5}{|l|}{ Socio-economic characteristics } \\
\hline Log real equivalent net household income & $0.1707 * *$ & 2.29 & $0.1740 * *$ & 2.33 \\
\hline Log real equivalent household rents $/ \mathrm{m}^{2}$ & $-0.0436 * *$ & -1.98 & $-0.0441 * *$ & -2.01 \\
\hline \multicolumn{5}{|l|}{ Migration effects } \\
\hline Not migrating 'across' municipalities & \multicolumn{2}{|c|}{ Reference group } & \multicolumn{2}{|c|}{ Reference group } \\
\hline Migrating 'across' municipalities & $0.2918 * *$ & 2.52 & $0.2781 * *$ & 2.43 \\
\hline Migration distance & -0.0557 & -0.45 & -0.0441 & -0.39 \\
\hline \multicolumn{5}{|l|}{$\underline{\text { Regional economic characteristics }}$} \\
\hline Distance from the nearest large city & & & 0.0011 & 0.18 \\
\hline Log of regional real purchasing power & & & $1.3735 * *$ & 2.47 \\
\hline Regional unemployment & & & -0.0055 & -0.39 \\
\hline Individual fixed effects & Yes & & Yes & \\
\hline Year effects & Yes & & Yes & \\
\hline Number of persons & 9,315 & & 9,315 & \\
\hline Average observation per person & 4.5 & & 4.5 & \\
\hline Observations & 41,764 & & 41,764 & \\
\hline R-squared within & 0.0220 & & 0.0227 & \\
\hline
\end{tabular}

Tab. 4: Migration effects and regional economic characteristics

Source: Own calculations. All models estimated by OLS. Robust standard errors clustered for person number and t-statistics reported. * indicates significant at the 10 percent level, ** at the 5 percent level, and *** at the 1 percent level. Socio-economic controls as provided in Table 1 are included but not presented here.

impact on migration effects. Accordingly, we forgo consideration of social ties in subsequent model specifications.

In a third extension of the baseline model presented in Table 4, we control for regional economic characteristics alongside housing and neighborhood characteristics. The sample is that of the model with housing and neighborhood characteristics. We find that an increase in regional purchasing power has a positive diminishing effect on life satisfaction, which is significant at the 5 percent level. These findings suggest that the wealth of a region, as measured by purchasing power, provides positive externalities for individuals living in that region. Other regional economic characteristics, such as distance from the nearest large city and regional unemployment levels, have no significant effect on life satisfaction.

Comparing columns (1) and (2) of Table 4, we find that controlling for regional economic characteristics reduces the coefficient of migration by 5 percent. The effect of migration distance remains negative and insignificant. The effect on socio-economic characteristics is small: the positive coefficient for income is 2 percent larger, while the negative coefficient for housing costs per $\mathrm{m}^{2}$ increases by 1 percent. 


\begin{tabular}{|c|c|c|c|c|c|c|}
\hline \multirow[b]{2}{*}{ Life satisfaction } & \multicolumn{2}{|c|}{$\begin{array}{c}\text { (1) } \\
\text { Housing \& economic }\end{array}$} & \multicolumn{2}{|c|}{$\begin{array}{c}\text { (2) } \\
\text { Housing, economic \& } \\
\text { labor }\end{array}$} & \multicolumn{2}{|c|}{$\begin{array}{c}\text { (3) } \\
\text { Final Model: } \\
\text { Housing, economic, labor \& } \\
\text { instrumentation }\end{array}$} \\
\hline & Coef. & t-stat & Coef. & t-stat & Coef. & t-stat \\
\hline \multicolumn{7}{|l|}{ Socio-economic characteristics } \\
\hline Log real equivalent net hous ehold income & $0.3589 * * *$ & 4.36 & $0.3514 * * *$ & 4.35 & $1.3900 * *$ & 2.47 \\
\hline Log real equivalent household rents $/ \mathrm{m}^{2}$ & $-0.0437 *$ & -1.69 & $-0.0437 *$ & -1.69 & $-0.0554 * *$ & -2.13 \\
\hline \multicolumn{7}{|l|}{$\underline{\text { Migration effects }}$} \\
\hline Not migrating 'across' municipalities & \multicolumn{2}{|c|}{ Reference group } & \multicolumn{2}{|c|}{ Reference group } & \multicolumn{2}{|c|}{ Reference group } \\
\hline Migrating 'across' municipalities & $0.2853 * * *$ & 2.87 & $0.2817 * * *$ & 2.80 & $0.2952 * * *$ & 2.98 \\
\hline Migration distance & $-0.1508 *$ & -1.69 & $-0.1542 *$ & -1.73 & $-0.1443 *$ & -1.66 \\
\hline \multicolumn{7}{|l|}{$\underline{\text { Labor characteristics }}$} \\
\hline Permanent contract & & & \multicolumn{2}{|c|}{ Reference group } & \multicolumn{2}{|c|}{ Reference group } \\
\hline Temporary contract & & & -0.0631 & -0.89 & 0.0018 & 0.02 \\
\hline Job tenure & & & $-0.0145 * *$ & -1.81 & -0.0127 & -1.64 \\
\hline Actual working hours & & & $0.0284 * * *$ & 2.73 & $0.0278 * * *$ & 2.61 \\
\hline \multirow[t]{2}{*}{ Acutal working hours squared } & & & $-0.0003 * * *$ & -2.66 & $-0.0004 * * *$ & -2.73 \\
\hline & & & & & \multicolumn{2}{|l|}{ First stage } \\
\hline Log of predicted labor earnings & & & & & $0.0782 * * *$ & 6.87 \\
\hline Individual fixed effects & Yes & & Yes & & Yes & \\
\hline Year effects & Yes & & Yes & & Yes & \\
\hline Number of persons & 6,894 & & 6,894 & & 6,894 & \\
\hline Average observation per person & 4.3 & & 4.3 & & 4.3 & \\
\hline Observations & 29,675 & & 29,675 & & 29,675 & \\
\hline Kleibergen-Paap rk LM statistic & - & & - & & $40.567 * * *$ & \\
\hline Kleibergen-Paap rk Wald F statistic & - & & - & & 47.182 & \\
\hline
\end{tabular}

Tab. 5: Migration effects and income instrumentation

Source: Own calculations. All models estimated by OLS. Robust standard errors clustered for person number and t-statistics reported. * indicates significant at the 10 percent level, ** at the 5 percent level, and $* * *$ at the 1 percent level. Socio-economic controls as provided in Table 1 are included but not presented here.

In a fourth and final extension of the baseline model presented in Table 5, we instrument income using predicted labor earnings while controlling for housing, neighborhood and regional economic characteristics. This reduces the sample size from 41,764 to 29,675 and the number of migrants from 465 to 340 . We compare the results of two specifications without income instrumentation to the one with instrumentation: a specification with housing, neighborhood, and regional economic characteristics (column 1), a specification with further controls for labor characteristics (column 2) (see Luechinger, 2009 or Vendrik, 2013), and, finally, a specification instrumenting for income (column 3). ${ }^{15}$ In the non-instrumented model with labor characteristics in (column 2), we find that job tenure has a negative impact on life satisfaction and that actual working hours have a highly significant inverse U-shaped effect as established in the literature (see Luechinger, 2009). Comparing the results to those in column (1), we find that controlling for labor characteristics has a small effect on the estimated

\footnotetext{
${ }^{15}$ Following Luechinger (2009), we also drop self-employed people from the sample in this model specification because they tend to be more reluctant about disclosing their income.
} 
coefficients for income, housing costs per $\mathrm{m}^{2}$, and migration (maximum 2 percent change). The effect of migration distance is still negative, but compared to the results presented in Table 4, it is now significant at the 10 percent level in all specifications presented in Table 5.

When instrumenting the income variable (column 3 in Table 5), we find that the instrument passes the under-identification test of Kleibergen-Paap rk LM statistic of 40.57 (at a significance level of 1 percent) and the weak identification test of Kleibergen-Paap rk Wald F statistic of 47.18 (compared to the conventional required value of 10). Comparing the results in columns (2) and (3), we find that the income coefficient is more than three times larger when instrumented.

Instrumenting the income variable has an effect on the coefficients of other control variables as well. The positive effect of migrating on life satisfaction increases, the coefficient is 5 percent larger. The negative effect of housing costs per $\mathrm{m}^{2}$ increases by more than 25 percent. The negative effect of migration distance decreases by 6 percent. Our results confirm earlier studies (e.g. Luechinger, 2009 or Vendrik, 2013) in underlining the importance of controlling for income endogeneity in empirical life-satisfaction analyses.

\section{Robustness}

The previous section has confirmed the importance of income instrumentation in our analysis. In the following, we use the specification with income instrumentation (fourth and final extension of the model; column (3) of Table 5) for a number of robustness checks. First, we examine the robustness of socio-economic and migration effects to adding further controls for labor characteristics, which are used in the literature when instrumenting the income variable with predicted labor earnings (see Luechinger, 2009) and which we have not yet considered in our final model specification. More specifically, we additionally control for job status (blue-collar, white-collar, managerial position, public services, trainee). The results (not presented) are similar to those found in our final model specification (Table 5, column 3).

Second, we tested various other specifications of distances to cities (used as a control for regional economic characteristics in column (2), Table 4) to rule out any effect from the choice of the distance variable on the outcome of our analysis. As an alternative to Euclidean distance from large cities, we used driving distance to major centers provided by the BBSR. “Major centers” captures not only large cities, but also smaller cities that function as major centers. We also tested for various specifications, including distance variables as squared terms, in addition to the level and a logarithmic transformation. None of these different 
specifications (not presented) yield higher significance levels for coefficients, nor do effects from migration change, the main focus of our analysis.

\section{Monetizing Regional Amenities}

Using the marginal rate of substitution between the effect of migration and individual income, it is possible to assign a monetary value to the trade-off between income and migration. According to our theoretical model, this provides us with information about the income changes required to offset changes in regional amenities, which can be calculated as follows:

$$
\text { WTP for regional amenities }=-\frac{\partial Y}{\left.\partial M\right|_{d L S} \equiv 0}=\frac{\beta_{a}}{\beta_{y}} Y_{m}
$$

with $Y$ being real equivalent net household income, $M$ the migration dummy, $\beta_{a}$ the estimated coefficients of the migration dummy, $\beta_{y}$ the coefficients of the logarithm of real equivalent net household income, and $Y_{m}$ median real equivalent net household income.

Using results from column (3) in Table 5, the WTP of migrants for an increase in regional amenities provided by the monthly income change is $€ 371$ (evaluated in terms of a monthly median household income of $€ 1,764$, see Table 6 ), which is statistically significant at the 5 percent level, equivalent to 21 percent of household income. ${ }^{16}$ As we do not account for discounted future income, this value can stand as a short-term measure of the benefits from regional amenities (see Schündeln, 2007, for further discussion).

Analogously to obtaining a WTP for an increase in regional amenities, we calculate for migrants a WTP for lower housing costs and shorter migration distance (our measure of the costs of migration) as follows:

$$
\begin{aligned}
& \text { WTP for housing costs }=-\frac{\delta Y}{\delta R]_{j}} \underset{d L S \equiv 0}{=\frac{\widehat{\beta}_{h}}{\widehat{\beta}_{y}} \frac{Y_{m}}{R_{m}} \Delta S_{m}} \\
& \text { WTP for migration distance }=-\frac{\delta Y}{\delta D]_{d L S \equiv 0}}=\frac{\widehat{\beta}_{d}}{\widehat{\beta}_{y}} Y_{m} D_{m}
\end{aligned}
$$

with $Y$ being real equivalent net household income, $R$ real equivalent housing costs per $\mathrm{m}^{2}, D$ distance of migration, $\beta_{h}$ estimated parameter for real equivalent housing costs per $\mathrm{m}^{2} \beta_{d}$

\footnotetext{
${ }^{16}$ Evaluated in terms of a mean monthly household income of $€ 2,089$, WTP for changes in regional amenities is $€ 439$.
} 


\begin{tabular}{lccc}
\hline & \multicolumn{2}{c}{$\begin{array}{c}\text { Evaluated in terms of monthly } \\
\text { median income of } € 1,764\end{array}$} \\
& Estimate & z-value & \% of income \\
\hline Regional amenities $^{\mathrm{a}}$ & $371^{* *}$ & 1.99 & 21 \\
Housing costs $^{\mathrm{a}}$ & $-48^{*}$ & -1.86 & 3 \\
Migration distance $^{\mathrm{b}}$ & -23 & -1.34 & 1.5 \\
\hline
\end{tabular}

Tab. 6: WTP estimates for regional amenities, housing costs, and migration distance per person. Source: Own calculations. Estimates derived from column (3) of Table 5. Robust standard errors clustered for person number. T-statistics obtained using the delta method. * indicates significant at the 10 percent level, ** at the 5 percent level, and $* * *$ at the 1 percent level. ${ }^{\text {a }}$ WTPs for housing costs evaluated in terms of real median equivalent rents per $\mathrm{m}^{2}$ of $€ 2$ (adjusted by OECD equivalence scale, see Section 4) and median change in the size of house/flat for migrants of $15 \mathrm{~m}^{2}$. ${ }^{\mathrm{b}}$ WTPs for migration distance evaluated in terms of median migration distance of $13 \mathrm{~km}$.

estimated parameter for migration distance, $\beta_{y}$ estimated parameter for the logarithm of real equivalent net household income, $Y_{m}$ median of real equivalent household income, $R_{m}$ median of real equivalent housing costs per $\mathrm{m}^{2}, \Delta S_{m}$ change in the size of house/flat for migrants, and $D_{m}$ median migration distance in $\mathrm{km}$.

The WTP of migrants for a decrease in housing costs as provided by the monthly income change is $€ 48$ (evaluated in terms of monthly median equivalent housing costs per $\mathrm{m}^{2}$ of $€ 2$ and the median change in size of house/flat of $15 \mathrm{~m}^{2}$, see Table 6), which is statistically significant at the 10 percent level, corresponding to 3 percent of household income. ${ }^{17}$ The WTP for a decrease in migration distance as provided by the monthly income change is $€ 23$ (evaluated in terms of a median migration distance of $13 \mathrm{~km}$, see Table 6), which represents 1.5 percent of household income. ${ }^{18}$ However, the WTP for migration distance is statistically no different from zero.

Several issues concerning the value of regional amenities as provided by WTP estimates are worthy of note. First, accounting for income endogeneity has a considerable effect on our empirical results. As the income coefficient is used as a denominator when calculating the trade-off between income and regional amenities, estimates for regional amenities would be overestimated if income were not instrumented; in our case values would be 3.5 times larger. Our value is slightly above the findings in the literature, according to which estimates increase by a factor of between two and three when instrumenting income with predicted labor earnings (see Luechinger, 2009 or Vendrik, 2013). However, these studies also tend to consider much longer sample periods.

\footnotetext{
${ }^{17}$ Evaluated in terms of a monthly mean household income of $€ 2,089$ and monthly mean rents per $\mathrm{m}^{2}$ of $€ 26$, WTP for changes in housing costs is $€ 51$.

${ }^{18}$ Evaluated in terms of a monthly mean household income of $€ 2,089$ and a mean migration distance of $57 \mathrm{~km}$, WTP for migration distance is $€ 119$.
} 
Second, accounting for migration costs in the empirical model is of major importance, as otherwise, changes in life satisfaction understate the correct value of changes in regional amenities. If people decide to migrate to a specific region, ceteris paribus, benefits from regional amenities must be large enough to cover migration costs. In Bayer et al. (2009), for example, the estimated benefits of better air quality are 3.5 times higher in a residential sorting model compared to results of a hedonic regression without migration costs. ${ }^{19}$ Our estimates suggest that benefits from regional amenities are 1.5 times larger when controlling for migration costs (results for a model without migration costs are not presented). ${ }^{20}$ Accordingly, accounting for migration costs is of major importance not only in hedonic analyses but also in life-satisfaction analyses aiming at estimating benefits from regional amenities based on migration decisions.

Third, accounting for housing costs per $\mathrm{m}^{2}$ in the empirical model has a negligible effect on our estimates for benefits from changes in regional amenities compared to accounting for migration costs. However, this does not in itself suggest excluding housing costs per $\mathrm{m}^{2}$ from empirical life-satisfaction analyses on internal migration. First, their level effects are controlled for by individual fixed effects in our analysis. Second, not only is their effect statistically different from zero, they also play a crucial role in explaining decisions to migrate by acting as a compensating counterpart to benefits from regional amenities indicated by the findings from our empirical analysis.

\section{Conclusions}

This study is the first to link economic theory with empirical life-satisfaction analyses of internal migration. Unlike earlier empirical life-satisfaction analyses, ours enables us to estimate effects on a lower level of aggregation, distinguishing between the costs and benefits of migration as suggested by economic theory. More specifically, we distinguish four factors: (1) benefits from regional amenities, (2) benefits from income, (3) housing costs, and (4) migration costs. The major advantages of our analysis are its high level of regional disaggregation combined with individual panel information, thus permitting not only a detailed analysis of migration decisions, but also controlling for selection bias by applying

\footnotetext{
${ }^{19}$ The WTP for a one-unit reduction in ambient concentration of particulate matter increases from \$55 to \$185 per year.

${ }^{20}$ Measures for benefits from regional amenities decrease from $€ 370$ evaluated in terms of median household income ( $€ 439$ evaluated in terms of mean household income) to $€ 265$ ( $€$ 313). This represents a reduction from $21 \%$ of household income to $15 \%$.
} 
individual fixed effects. To account for endogeneity of income, we apply an instrumentation strategy.

We find that short-term benefits from changes in regional amenities due to migration represent 21 percent of household income. These benefits from regional amenities are much larger than migration-related income gains, which represent only 3 percent of household income. These benefits are partly offset by housing costs and migration costs representing 3 percent and 1.5 percent of household income, respectively. In statistical terms, however, migration costs are not significantly different from zero.

Several insights from our robustness analyses are worthy of note. First, benefits from changes in regional amenities are overestimated if endogeneity of income is not accounted for, the value then being 3.5 times larger. This is close to findings in the literature. Second, the consideration of migration costs in our empirical life-satisfaction model turns out to increase benefits from regional amenities by a factor of 1.5. This emphasizes the importance of controlling for migration costs in empirical life-satisfaction analyses to avoid omitted variable bias when looking to derive benefits from regional amenities as recognized with regard to hedonic studies.

\section{Aknowledgements}

We are grateful to the SOEP team for providing regional data. The authors wish to thank Annekatrin Niebuhr, Eckhardt Bode, and Frank Birkenbach for helpful comments. Regional data was kindly provided by the BBSR. Financial support from the German Ministry of Research and Technology (01LL0901A) is gratefully acknowledged. 


\section{Appendix}

\section{Appendix A.1:}

Assuming a Cobb-Douglas utility function, the maximization problem that yields the indirect utility function is stated as the following maximization problem:

$\max _{C, H} L=C_{i, j}^{\alpha c} H_{i, j}{ }^{\alpha h} e^{\beta a A j} e^{\beta m c M C i}+\lambda\left(Y_{i, j}-C_{i, j}-R_{i, j} H_{i, j}\right)$

In a first step, we take the first derivatives of the Lagrangian with respect to consumption and housing:

(1) $\alpha_{c} C_{i, j}^{\alpha c-1} H_{i, j}^{\alpha h} e^{\beta a A j} e^{\beta m c M C i}=\lambda$

(2) $\alpha_{h} C_{i, j}^{\alpha c} H_{i, j}^{\alpha h-1} e^{\beta a A j} e^{\beta m c M C i}=\lambda R_{i, j}$

In a second step, we divide (1) by (2):

$\left(\alpha_{d} / \alpha_{h}\right)\left(H_{i, j} / C_{i, j}\right)=1 / R_{i, j}$

In a third step, we solve for $C_{i, j}$ and $H_{i, j}$, which yields optimal consumption bundles:

$C_{i, j}^{*}=Y_{i, j} /\left(1+\left(\alpha_{h} / \alpha_{c}\right)\right)$

$H_{i, j}{ }^{*}=Y_{i, j} /\left(\left(\alpha_{c} / \alpha_{h}\right) R_{i, j}+R_{i, j}\right)$

Finally, we put optimal consumption bundles into the utility function and take the logarithm. This yields the indirect utility function:

$\ln V_{i, j}=\beta+\beta_{y} \ln Y_{i, j}-\beta_{h} \ln R_{i, j}+\beta_{a} A_{j}+\beta_{m c} M C_{i}$,

where $\alpha h / \beta_{y}$ is the fraction of income spent on housing, $\beta=\alpha_{c} \ln \left(\alpha_{c} /\left(\alpha_{c^{+}} \alpha_{h}\right)\right)+\alpha_{h} \ln \left(\alpha_{h} /\left(\alpha_{c^{+}} \alpha_{h}\right)\right.$, $\beta_{y}=\alpha c+\alpha h$ and $\beta_{h}=\alpha h$. 
Appendix A.2: Summary statistics

\begin{tabular}{|c|c|c|c|}
\hline Variable & Mean & SD & Year \\
\hline \multicolumn{4}{|l|}{ Life satisfaction } \\
\hline Life satisfaction ( 1 = very dissatisfied and $10=$ very satis fied $)$ & 6.9586 & 1.7298 & 2006-2010 \\
\hline \multicolumn{4}{|l|}{ Income and housing } \\
\hline Log of real net household equivalent income (log of Euros) & 9.9093 & 0.5298 & 2006-2010 \\
\hline Log of real rents per square meter (log of Euros) & 2.7090 & 1.4136 & $2006-2010$ \\
\hline \multicolumn{4}{|l|}{ Demographic characteristics } \\
\hline Number of persons living in household & 2.9083 & 1.2313 & 2006-2010 \\
\hline Number of children in household & 0.6020 & 0.9242 & 2006-2010 \\
\hline Age of individual squared & 2,185 & 976 & 2006-2010 \\
\hline \multicolumn{4}{|l|}{ Health status } \\
\hline *No hospitalization last year $(1=$ yes, $0=$ no $)$ & 0.9056 & 0.2924 & 2006-2010 \\
\hline Hospitalization last year $(1=$ yes, $0=$ no $)$ & 0.0944 & 0.2924 & 2006-2010 \\
\hline \multicolumn{4}{|l|}{ Marital status } \\
\hline *Single, not living with partner $(1=$ yes, $0=$ no $)$ & 0.1522 & 0.3592 & 2006-2010 \\
\hline Single, living with partner $(1=$ yes, 0 = no) & 0.0538 & 0.2256 & 2006-2010 \\
\hline Married, living with partner $(1=$ yes, 0 = no $)$ & 0.6727 & 0.4692 & 2006-2010 \\
\hline Separated, not living with partner $(1=$ yes, $0=$ no $)$ & 0.0126 & 0.1117 & 2006-2010 \\
\hline Separated, living with partner $(1=$ yes, $0=$ no $)$ & 0.0033 & 0.0574 & 2006-2010 \\
\hline Divorced, not living with partner $(1=$ yes, $0=$ no $)$ & 0.0557 & 0.2293 & 2006-2010 \\
\hline Divorced, living with partner $(1=$ yes, $0=$ no $)$ & 0.0295 & 0.1693 & 2006-2010 \\
\hline Widowed, not living with partner $(1=$ yes, $0=$ no $)$ & 0.0160 & 0.1254 & $2006-2010$ \\
\hline Widowed, living with partner $(1=$ yes, $0=$ no $)$ & 0.0042 & 0.0644 & $2006-2010$ \\
\hline \multicolumn{4}{|l|}{ Education level } \\
\hline Years in education & 12.5101 & 2.6947 & 2006-2010 \\
\hline \multicolumn{4}{|l|}{ Employment status } \\
\hline *Non-working $(1=$ yes, 0 = no $)$ & 0.1451 & 0.3523 & 2006-2010 \\
\hline Unemployed $(1=$ yes, 0 = no $)$ & 0.0569 & 0.2317 & 2006-2010 \\
\hline Student $(1=$ yes, 0 = no $)$ & 0.0183 & 0.1340 & 2006-2010 \\
\hline Military, civilian services ( 1 = yes, $0=$ no) & 0.0087 & 0.0931 & 2006-2010 \\
\hline Working $(1=$ yes, $0=$ no $)$ & 0.7709 & 0.4203 & 2006-2010 \\
\hline \multicolumn{4}{|l|}{ Citizen status } \\
\hline *German citizen $(1=$ yes, $0=$ no $)$ & 0.9462 & 0.2257 & 2006-2010 \\
\hline Non-German citizen $(1=$ yes, $0=$ no $)$ & 0.0538 & 0.2257 & 2006-2010 \\
\hline \multicolumn{4}{|l|}{ Interview status } \\
\hline First interview $(1=$ yes, $0=$ no $)$ & 0.0195 & 0.1383 & 2006-2010 \\
\hline Second interview $(1=$ yes, $0=$ no $)$ & 0.0214 & 0.1448 & 2006-2010 \\
\hline Third or subsequent interview $(1=$ yes, $0=$ no $)$ & 0.9591 & 0.1981 & $2006-2010$ \\
\hline \multicolumn{4}{|l|}{ Mover status } \\
\hline *No moves $(1=$ yes, 0 = no $)$ & 0.9748 & 0.1569 & 2006-2010 \\
\hline Move 'within' municipalities $(1=$ yes, $0=$ no $)$ & 0.0252 & 0.1569 & $2006-2010$ \\
\hline \multicolumn{4}{|l|}{ Migration characteristics } \\
\hline *Not migrating 'across' municipalities $(1=$ yes, $0=$ no $)$ & 0.9874 & 0.1117 & $2006-2010$ \\
\hline Migrating 'across' municipalities $(1=$ yes, $0=$ no) & 0.0126 & 0.1117 & 2006-2010 \\
\hline Migration distance (in $100 \mathrm{~km}$ ) & 0.0080 & 0.1503 & $2006-2010$ \\
\hline \multicolumn{4}{|l|}{ Year dummies } \\
\hline *Year $2006(1=$ yes, 0 = no $)$ & 0.2053 & 0.4039 & 2006-2010 \\
\hline Year 2007 (1 = yes, 0 = no $)$ & 0.2025 & 0.4019 & 2006-2010 \\
\hline Year $2008(1$ = yes, 0 = no $)$ & 0.1991 & 0.3993 & 2006-2010 \\
\hline Year 2009 (1 = yes, 0 = no $)$ & 0.1973 & 0.3980 & 2006-2010 \\
\hline Year $2010(1=$ yes, $0=$ no $)$ & 0.1958 & 0.3968 & 2006-2010 \\
\hline Total number of obs ervations & 43,941 & & \\
\hline
\end{tabular}

Source: Own calculations based on SOEP. *Reference categories. Following Luechinger (2009), variables describing marital status are a combination of standard information on marital status (such as being married) and living or not living together with a partner. Abbreviations: $\mathrm{BBSR}=$ Bundesinstitut für Bau-, Stadt- und Raumforschung; SD=Standard Deviation. 
Table A.3: Settlement-structural municipality types aggregation

\begin{tabular}{ll}
\hline Aggregation & \multicolumn{1}{c}{ Settlement structural municipality types (BBSR) } \\
\hline Large cities & Major large city \\
& Large city in agglomeration county \\
& Large city in urban county \\
\hline & Center of high-density agglomeration county \\
& Other municipality in high-density agglomeration county \\
& Center of dense agglomeration county \\
& Other municipality in dense agglomeration county \\
& Center of rural agglomeration county \\
& Other municipalities in rural agglomeration county \\
& Center of dense urban county \\
& Other municipality in dense urban county \\
& Center of rural urban county \\
& Other municipalities in rural urban county \\
& Center of rural county with higher density \\
& Other municipalities in rural county with higher density \\
& Center of rural county with lower density \\
& Other municipality in rural county with lower density \\
\hline
\end{tabular}

Source: Own compilation based on BBSR. 
Table A.4: Summary statistics for extensions of the baseline model

\begin{tabular}{|c|c|c|c|}
\hline Variable & Mean & SD & Year \\
\hline \multicolumn{4}{|l|}{ Housing characteristics } \\
\hline Logarithm of size of house/flat in $\mathrm{m}^{2}$ & 4.6548 & 0.4082 & 2006-2010 \\
\hline Construction year: $<1918$ & 0.1511 & 0.3581 & 2006-2010 \\
\hline Construction year: 1918 - 1948 & 0.1472 & 0.3543 & 2006-2010 \\
\hline Construction year: 1949 - 1971 & 0.2254 & 0.4179 & 2006-2010 \\
\hline Construction year: 1972 - 1980 & 0.1400 & 0.3470 & 2006-2010 \\
\hline Construction year: 1981 - 1990 & 0.1287 & 0.3348 & 2006-2010 \\
\hline Construction year: 1991 - 2000 & 0.1536 & 0.3606 & 2006-2010 \\
\hline *Construction year: $>2000$ & 0.0540 & 0.2261 & 2006-2010 \\
\hline *Not owner of house/flat & 0.3914 & 0.4881 & 2006-2010 \\
\hline Owner of house/flat & 0.6086 & 0.4881 & 2006-2010 \\
\hline *No central heating & 0.0315 & 0.1747 & 2006-2010 \\
\hline With central heating & 0.9685 & 0.1747 & 2006-2010 \\
\hline *No balcony/terrace & 0.1726 & 0.3779 & 2006-2010 \\
\hline With balcony/terrace & 0.8274 & 0.3779 & 2006-2010 \\
\hline *No basement & 0.0445 & 0.2061 & 2006-2010 \\
\hline With basement & 0.9555 & 0.2061 & 2006-2010 \\
\hline *No garden & 0.2799 & 0.4490 & 2006-2010 \\
\hline With garden & 0.7201 & 0.4490 & 2006-2010 \\
\hline *No kitchen in house/flat & 0.0037 & 0.0604 & 2006-2010 \\
\hline Kitchen in house/flat & 0.9963 & 0.0604 & 2006-2010 \\
\hline *No hot running water/boiler in house/flat & 0.0021 & 0.0453 & 2006-2010 \\
\hline With hot running water/boiler in house/flat & 0.9979 & 0.0453 & 2006-2010 \\
\hline *No telephone in house/flat & 0.0039 & 0.0625 & 2006-2010 \\
\hline With telephone in house/flat & 0.9961 & 0.0625 & 2006-2010 \\
\hline *House/flat in good shape & 0.7211 & 0.4485 & 2006-2010 \\
\hline House/flat needs to be refurbished & 0.2789 & 0.4485 & 2006-2010 \\
\hline * Detached or semi-detached house & 0.4092 & 0.4917 & 2006-2010 \\
\hline Farm building & 0.0331 & 0.1788 & 2006-2010 \\
\hline Terraced house & 0.1896 & 0.3920 & 2006-2010 \\
\hline Apartment or other building & 0.3586 & 0.4796 & 2006-2010 \\
\hline High-rise building & 0.0096 & 0.0973 & 2006-2010 \\
\hline *Private household & 0.9994 & 0.0235 & 2006-2010 \\
\hline Hall of residence/home & 0.0006 & 0.0235 & 2006-2010 \\
\hline *Industrial area & 0.0049 & 0.0699 & 2006-2010 \\
\hline Residential area with old buildings & 0.3413 & 0.4742 & 2006-2010 \\
\hline Residential area with new buildings & 0.4255 & 0.4944 & 2006-2010 \\
\hline Mixed or other area & 0.2242 & 0.4171 & 2006-2010 \\
\hline Commercial center & 0.0041 & 0.0637 & 2006-2010 \\
\hline Total number of observations & 41,764 & & \\
\hline \multicolumn{4}{|l|}{ Social ties } \\
\hline Social participation & 2.8419 & 0.6540 & 2006-2010 \\
\hline Total number of obs ervations & 24,280 & & \\
\hline \multicolumn{4}{|c|}{ Regional economic characteristics at the municipality level } \\
\hline Distance from nearest large cities (in km) & 23.5681 & 23.7347 & 2006-2010 \\
\hline Log regional real purchasing power (in € per head) & 2.8633 & 0.1404 & 2006-2010 \\
\hline Regional unemployment (in \%) & 9.5958 & 4.8445 & 2006-2010 \\
\hline Total number of obs ervations & 41,764 & & \\
\hline \multicolumn{4}{|l|}{ Labor characteristics } \\
\hline Log of predicted labor earnings (in €) & 9.9478 & 0.6125 & 2006-2010 \\
\hline *Temporary contract & 0.0833 & 0.2763 & 2006-2010 \\
\hline Permanent contract & 0.9167 & 0.2763 & 2006-2010 \\
\hline Job tenure & 12.6455 & 10.3285 & 2006-2010 \\
\hline Actual working hours & 38.3714 & 12.9491 & 2006-2010 \\
\hline Actual working hours squared & $1,640.0360$ & 945.0331 & 2006-2010 \\
\hline
\end{tabular}

Source: Own calculations based on SOEP and BBSR. 


\section{References}

Atkinson, A. and F. Bourguignon (Eds.). 2000. Handbook of Income Distribution. Amsterdam: North-Holland.

Bayer, P., Nathaniel K., and C. Timmins. 2009. Migration and hedonic valuation: The case of air quality. Journal of Environmental Economics and Management 58(1): 1-14.

Deutsche Rentenversicherung Bund (DRV). 2013. Rentenversicherung in Zeitreihen. DRVSchriften 22: 1-334.

Dolan, P., T. Peasgood and M. White. 2008. Do we really know what makes us happy? A review of the economic literature on the factors associated with subjective well-being. Journal of Economic Psychology 29: 94-122.

Ferrer-i-Carbonell, A. and P. Fijters. 2004. How important is methodology for the estimates of the determinants of happiness? The Economic Journal 114(July): 641-659.

Frey, B. S. and A. Stutzer. 2002. What can economists learn from happiness research?. Journal of Economic Literature 40(2): 402-435.

Fuchs-Schündeln, N. and M. Schündeln. 2009. Who stays, who goes, who returns?. Economics of Transition 17(4): 703-738.

Graves, P.E. 1979. A Life-Cycle Empirical Analysis of Migration and Climate, by Race. Journal of Urban Economics 6: 135-147.

Graves, P.E. 1980. Migration and Climate. Journal of Regional Science 20: 227-237.

Graves, P.E. 1983. Migration with a Composite Amenity: the Role of Rents. Journal of Regional Science 23: 541-546.

Greenwood, M. J. 1997. Internal migration in developed countries. In Rozenzweig, M. R., Stark, O. (eds.), Handbook of Population and Family Economics 1: 647-720.

Headey, B., R. Muffels and G. G. Wagner. Choices which change life satisfaction: Similar results for Australia, Britain and Germany. Social Indicators Research 112.3 (2013): 725-748.

Irwin, E. G. 2002. The effects of open space on residential property value. Land Economics 78(4): 465-480.

Klaiber, A. H. and D. J. Phaneuf. 2010. Valuing open space in a residential sorting model of the Twin Cities. Journal of Environmental Economics and Management 60(2): 57-77. 
Krause, P. 1996. Berechnung von „Imputed-Rent“-Werten für das Sozio-oekonomische Panel (SOEP) 1984-1994, mimeo, Berlin.

Luechinger, Simon. 2009. Valuing Air Quality Using the Life Satisfaction Approach. The Economic Journal 119(536): 482-515.

Luttmer, E. F. P. 2005. Neighbors as negatives: relative earnings and well-being. Quarterly Journal of Economics 120(3): 963-1002.

Mäler, K. G. 1977. A note on the use of property in estimating marginal willingness to pay for environmental quality. Journal of Environmental Economics and Management 4: 355-369.

Moro, M., F. Brereton, S. Ferreira, and P. Clinch. 2008. Ranking Quality of Life Using Subjective Well-Being Data. Ecological Economics 65: 448-460.

Moulton, B.R. 1990. An Illustration of a Pitfall in Estimating the Effects of Aggregate Variables on Micro Unit. The Review of Economics and Statistics 72(2): 334-38.

Nowok, B., van Ham, M., Findlay, A. and V. Gayle (2013): Doe Migration Make You Happy? A Longitudinal Study of Internal Migration and Subjective Well-Being. Environment and Planning 45(4): 986-1002.

Porell, F.W. 1982. Intermetropolitan Migration and Quality of Life. Journal of Regional Science 22: 137-158.

Rappaport, J. 2007. Moving to nice weather. Regional Science and Urban Economics 37: 375-398.

Ree, J. de and R. Alessie. 2011. Life satisfaction and age: Dealing with underidentification in age-period-cohort models. Social Science and Medicine 73(1): 177-182.

Rosen, Sherwin. 1974. Hedonic prices and implicit markets: product differentiation in pure competition. The Journal of Political Economy: 34-55.

Roback, Jennifer. 1982. Wages, rents, and the quality of life. The Journal of Political Economy 90(6): 1257-1278.

Sandvik, Ed, Ed Diener, and Larry Seidlitz. 1993. Subjective well-being: The convergence and stability of self-report and non-self-report measures. Journal of Personality 61(3): 317342.

Schündeln, Matthias. 2007. Are immigrants more mobile than natives? Evidence from Germany. No. 3226. IZA Discussion Papers. 
Sinha, Paramita, and Maureen L. Cropper. 2013. The Value of Climate Amenities: Evidence from US Migration Decisions. No. w18756. National Bureau of Economic Research.

Socio-Economic Panel (SOEP). 2011. Data for the years 1984-2010, version 27. SOEP. doi: 10.5684/soep.v27.

Switek, Malgorzata. 2012. Internal migration and life satisfaction: Well-being effects of moving as a young adult. No. 7016. Discussion Paper Series, Forschungsinstitut zur Zukunft der Arbeit.

Vendrik, M. 2013. Adaptation, anticipation and social interaction in happiness: An integrated error-correction approach. Journal of Public Economics 105: 131-149.

Waltert, F. and F. Schläpfer. 2010. Landscape amenities and local development: A review of migration, regional economic and hedonic pricing studies. Ecological Economics 70(2): 141152.

Wagner, G., J. Frick, and J. Schupp. 2007. The German Socio-Economic Panel Study (SOEP)-Scope, Evolution and Enhancements. Schmollers Jahrbuch: Journal of Applied Social Science Studies/Zeitschrift für Wirtschafts-und Sozialwissenschaften 127: 139-169.

Welsch, H. and S. Ferreira. 2014. Environment, Well-Being, and Experienced Preference. International Review of Environmental and Resource Economics 7: 205-239.

Zabel, J. E. and K. A. Kiel. 2000. Estimating the demand for air quality in four US cities. Land Economics: 174-194.

Zumbro, T. 2014. The relationship between homeownership and Life Satisfaction in Germany. Housing Studies 29(3): 319-338. 